\title{
СУЧАСНИЙ ПОГЛЯД НА ЕТІОЛОГІЮ ТА ПАТОГЕНЕЗ ПЕРЕДРАКОВИХ ЗАХВОРЮВАНЬ I РАКУ ВУЛЬВИ
}

\author{
๑В. В. Дунаєвська' ${ }^{1,2}$, Т. Ф. Татарчук', Н. Ф. Захаренко ${ }^{3}$ \\ ДУ «lнститут педіатрії, акушерства і гінекології імені академіка О. М. Лук'янової НАМн України», Київ ${ }^{1}$ \\ Національний інститут раку, Київ \\ ДНУ «Центр інноваційних медичних технологій НАН України», Київ
}

PЕЗЮМЕ. Проблема дистрофічних захворювань і раку вульви до теперішнього часу залишається не вирішеною. В останні десятиліття відзначається збільшення числа дистрофічних захворювань вульви, на фоні яких у 9-49 \% випадків виникають злоякісні пухлини. Тому потрібно детальніше вивчити цю проблему.

Мета - визначити причини розвитку склерозуючого лишаю і раку вульви.

Матеріал і методи. Проведено обстеження 110 пацієнток зі склерозуючим лишаєм вульви, 60 хворих із раком вульви; 100 пацієнток у постменопаузі, які не мали клінічних проявів захворювань з боку вульви, склали групу контролю.

Результати. Встановлено, що число спостережень з високим вмістом естроген-рецепторів у нормальній тканині вульви склало 35,5 \%, тоді як при дистрофії вульви кількість спостережень з високим рівнем рецепторів склала лише 5,8 \%. При раку вульви в переважній більшості спостережень (85,6 \%) були відсутні естроген-рецептори. У міру збільшення тривалості постменопаузи кількість естроген-негативних результатів при склерозуючому лишаї зростає, складаючи загалом 58,8 \% всіх досліджень.

Висновок. Уявлення про особливості й етіологію виникнення дистрофічних процесів і раку вульви в постменопаузі формує диференційований підхід до реалізації профілактичних заходів, і в цьому сенсі профілактика набуває патогенетичної спрямованості. У наших дослідженнях доведена ключова роль порушення співвідношення метаболітів естрогену і вірусної інфекції в патогенезі дистрофічних процесів і раку вульви.

КлючовІ СловА: вульва; склерозуючий лишай; менопауза; постменопауза; дисплазія; рак; новоутворення; онкобілок; статеві губи; папілома.

Вступ. Рак вульви $€$ доволі рідкісним захворюванням серед злоякісних пухлин жіночих статевих органів. Епідеміологія раку вульви в нашій країні вивчена недостатньо. До групи ризику його виникнення належать пацієнтки з дистрофічними процесами (склерозуючим лишаєм) і дисплазіями вульви різного ступеня. У наших дослідженнях продемонстровано ключову роль порушення співвідношення метаболітів естрогену і вірусної інфекції в патогенезі дистрофічних процесів і раку вульви.

Більшість дослідників до основних етіологічних причин цих захворювань відносять порушення в системі нейроендокринного гомеостазу, що виникають у постменопаузі. Певне значення має й зниження рівня естроген-рецепторів у тканині вульви, що формується на фоні постменопаузи. Однак уся сукупність гормональних і рецепторних порушень, характерних для постменопаузи, не в змозі пояснити причину розвитку склерозуючого лишаю (СЛВ) і раку вульви (РВ). Усі ці порушення $\epsilon$ обов'язковими і неминучими факторами, які супроводжують постменопаузу. Разом з тим, тільки у невеликої кількості жінок (0,6 \% від загального числа гінекологічних захворювань) у постменопаузі розвивається СЛВ, і лише в одиниць - РВ.

Загальновідомо, що у переважної більшості пацієнток злоякісний процес виникає на фоні вікових інфолютивних змін вульви. Залишається відкритим питання, яким чином на фоні атрофічного стану виникає високопроліферативний процес, який механізм посилення проліферації епітелію вульви. Ми дотримуємося домінуючого погляду, що СЛ не може й не повинен розглядатися як облігатний передрак вульви. Однак саме на його фоні найчастіше згодом розвиваються диспластичні зміни і РВ.

Дистрофічні зміни вульви, згідно з сучасними уявленнями, включають патологічні процеси, що класифікуються як склерозуючий лишай, плоскоклітинна гіперплазія й змішані ураження. У зв'язку з великою варіабельністю і суперечностями між клінічними і морфологічними діагнозами, в 1993 р. при співпраці Міжнародного товариства з вивчення патології вульви і Міжнародного товариства 3 гінекологічної патології була прийнята нова класифікація захворювань вульви на підставі патоморфологічних змін зовнішніх статевих органів.

І. Доброякісні захворювання вульви:

- склерозуючий лишай;

- плоскоклітинна гіперплазія;

Інші дерматози.

II. Інтраепітеліальна неоплазія вульви (vulvar intraepithelial neoplasia, VIN).

- VIN 2 - середня дисплазія;

- VIN 3 - тяжка дисплазія і carcinoma in situ.

III. Рак вульви.

Мета - визначити причини розвитку склерозуючого лишаю і раку вульви. 
Огляди літератури, оригінальні дослідження, погляд на проблему, випадок з практики, короткі повідомлення

Матеріал і методи дослідження. В останні десятиліття відзначається збільшення числа дистрофічних захворювань вульви, на фоні яких в 9-49 \% випадків виникають злоякісні пухлини. Зростання числа пацієнток, у яких РВ виник на фоні попередніх дистрофічних процесів, робить проблему дистрофічних захворювань актуальною з позиції не тільки своєчасної діагностики, а й профілактики злоякісних пухлин. РВ $є$ відносно рідкісною хворобою, що займає 4 місце (3-4 \%) серед злоякісних пухлин жіночих статевих органів [1]. На РВ переважно страждають жінки похилого віку, не менше 75 \% захворілих старше 60 років, а близько 35 \% хворих - старше 70-80 років. Незважаючи на візуальну доступність цього захворювання для сучасної діагностики, понад половина хворих звертаються за на лікуванням 3 місцево поширеними процесами, що знижує можливості радикальних методів лікування. За даними FIGO, 5-річне виживання хворих на PB становить всього 50,0 \% [2, 3].
Поява злоякісної пухлини при СЛ - явище відносно рідкісне, тоді як осередки плоскоклітинної гіперплазії на шкірно-слизових покривах вульви мають значно більш виражену потенційну можливість злоякісної трансформації - 43,5%. РВ, який розвинувся на фоні дистрофічних процесів, характеризується повільнішим ростом, але частим розвитком місцевих рецидивів. Отже, СЛ, як модель патологічного процесу вульви, потребує розгляду з кількох позицій. По-перше, це захворювання виникає на фоні обов' язкового дефіциту естрогенів, клінічно достатньо вивчене, має чітку симптоматику і морфологічні параметри. По-друге, СЛ для пацієнток постменопаузального періоду $є$ найчастішим і обов' язковим етапом, що передує розвитку PB. Іншими словами, якщо з позицій морфогенезу СЛ не може і не повинен розглядатися як облігатний передрак вульви, то з клінічного погляду він таким, по суті, $\epsilon$.

На матеріалі наших досліджень обґрунтована вірогідна модель етіології та патогенезу РВ (рис. 1).

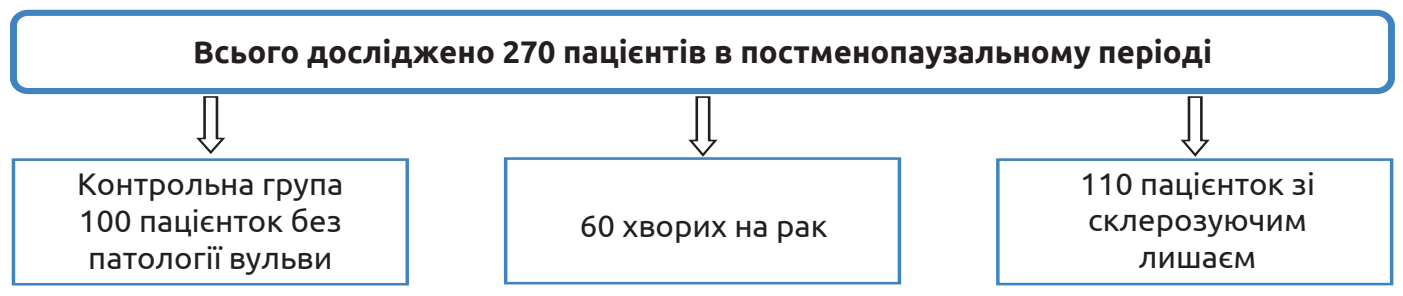

Рис. 1. Вірогідна модель етіології та патогенезу раку вульви.

Проведено обстеження 110 пацієнток зі СЛВ, 60 хворих на РВ; 100 пацієнток у постменопаузі, які не мали клінічних проявів захворювань з боку вульви, склали групу контролю.

Комплексне обстеження жінок включало:

1) аналіз скарг, генеративної функції, перенесеної гінекологічної та екстрагенітальної патології;

2) гінекологічний огляд;

3) вульвоскопію; дослідження мазка з вульви на онкоцитологію;
4) сонографію органів малого таза;

5) ПЛР-діагностику мазків з поверхні вульви та піхви;

6) морфологічне дослідження біоптату вульви;

7) імуногістохімічне дослідження естроген- i прогестерон-рецепторів у тканині вульви;

8) визначення індексу маси тіла;

9) визначення рівня і коефіцієнта співвідношення метаболітів естрогену: $16 \mathrm{a}-\mathrm{OHE} 1$ і 2-OHE1;

10) імуноферментний аналіз на онкобілок E7 (рис. 2).

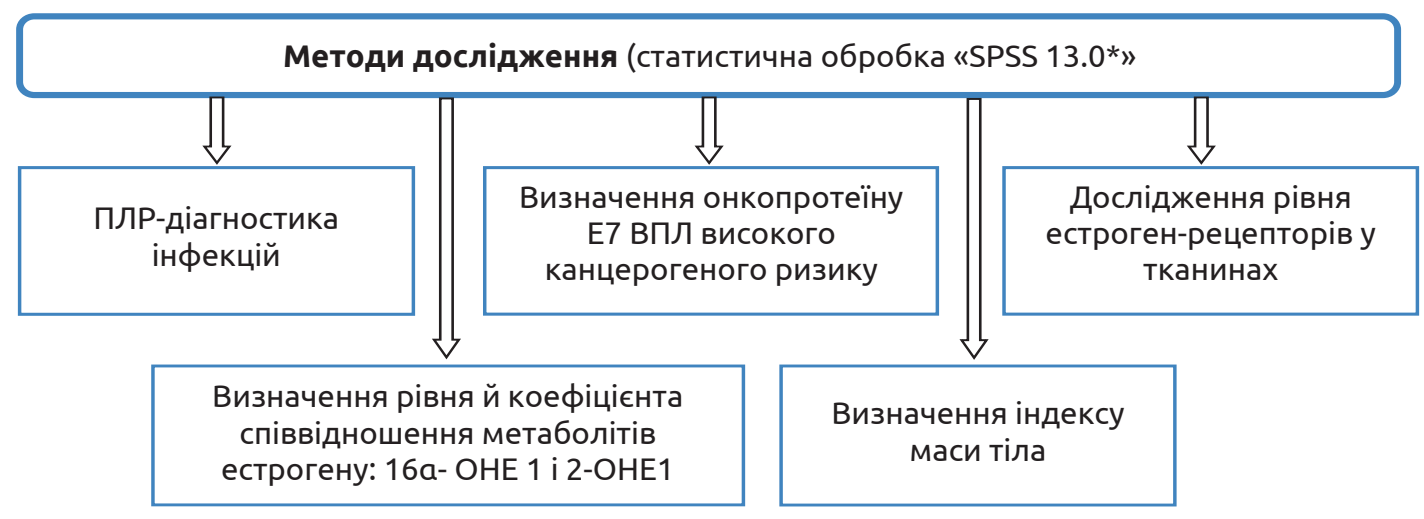

Рис. 2. Дизайн дослідження. 
Огляди літератури, оригінальні дослідження, погляд на проблему, випадок з практики, короткі повідомлення

Середній вік обстежених хворих на РВ склав $(62,7 \pm 0,7)$ років, хворих на СЛ - $(61,9 \pm 0,2)$ років, пацієнток контрольної групи - $(59,8 \pm 0,5)$ років. Середній вік настання менопаузи у групі хворих на РВ склав $(48,6 \pm 0,8)$ року, хворих на СЛ $-(59,3 \pm 0,3)$ років, пацієнток контрольної групи - $(48,7 \pm 0,2)$ років. Тривалість періоду постменопаузи коливалася від 1 до 25 років. Середня тривалість періоду постменопаузи в групі хворих на РВ склала $(15,2 \pm$ $0,5)$ років, у хворих СЛ - $(12,2 \pm 0,6)$ років, у пацієнток контрольної групи - $(11,5 \pm 0,3)$ років.

При аналізі скарг хворих на СЛ і РВ основним був свербіж у ділянці зовнішніх статевих органів, який виявлено у 95,4 \% жінок, сухість шкіри і слизової вульви - у 80,5 \%, диспареунія - у 15,6 \% пацієнток, дизурія - у 4,4 \%. Психоемоційні розлади виявлено у 30 \% пацієнток. Тривалість зазначених скарг склала $(11 \pm 0,3)$ років.
Локалізація первинного пухлинного вогнища при РВ відмічалася в основному в зоні великих i малих статевих губ (50,8 \%), клітора (20\%), на межі великих і малих статевих гу6 (28,5\%), задньої спайки $(15,7 \%)$.

Гінекологічний огляд пацієнток із СЛ дозволив виявити дистрофічні зміни в ділянці вульви, які проявлялися у вигляді стоншення й сухості шкірнослизового покриву вульви, малі статеві губи в більшості спостережень були згладжені, спостерігалися стоншення й атрофія великих статевих губ, вхід у піхву звужувався, шкіра і слизові мали пергаментний вигляд. При тривало існуючому захворюванні виявлено наявність синехій між великими і малими статевими губами, екскоріації. При наявності PB на шкірно-слизовому покриві вульви в більшості випадків були ерозивно-виразкові дефекти, часто з некротичними нашаруваннями (рис. 3).

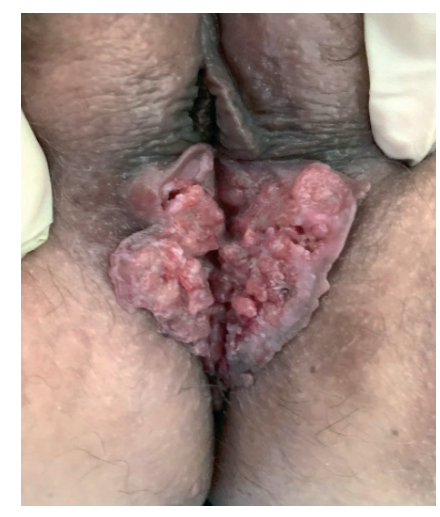

рак вульви на фоні кондиломатозного ураження



склерозуючий лишай з розвитком ерозивного епідерміту

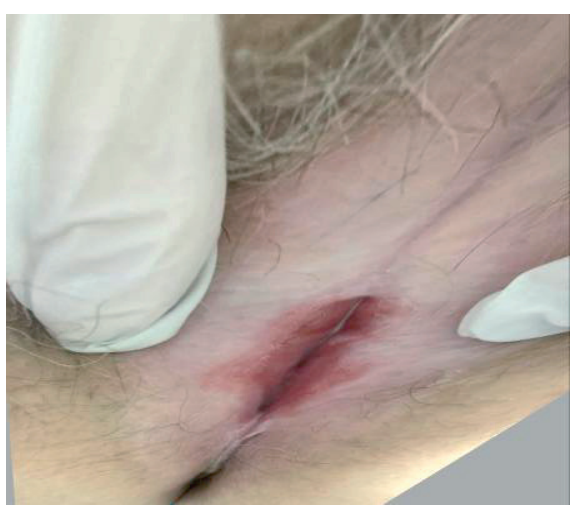

склерозуючий лишай вульви з повною атрофією вульви, клітора і малих статевих губ

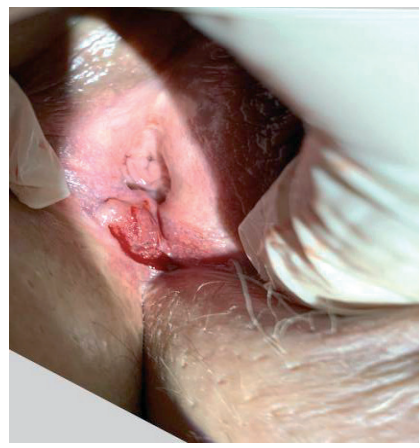

інфільтративно-набрякова форма раку

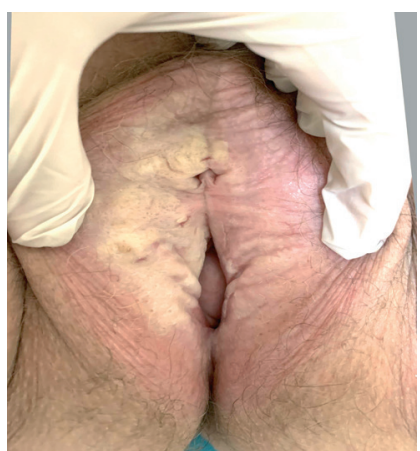

плоскоклітинний рак вульви

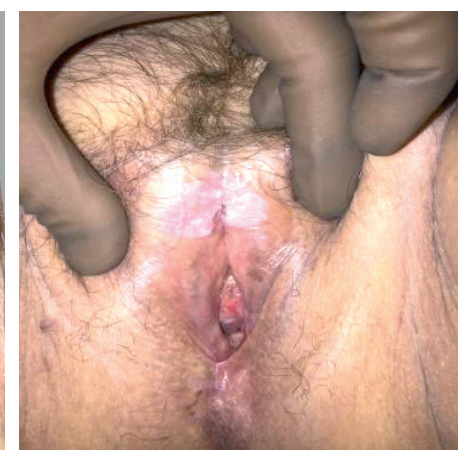

рак вульви in situ

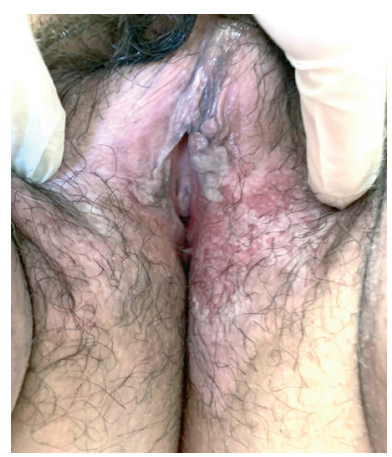

рак вульви in situ

Рис. 3. Різні варіанти ураження вульви при склерозуючому лишаю і раку вульви.

За стадіями РВ хворі були поділені наступним чином: 14 мали I стадію (23,3\%), 16 хворих - II (26,6 \%) і 14 хворих III (23,3 \%) стадії; IV стадія РВ діагностована в $16(26,6 \%)$ хворих.

Результати й обговорення. Ми вивчали рецепторний апарат тканини вульви у 255 пацієнток:
60 хворих на РВ, 110 пацієнток зі склерозуючим лишаєм і 85 пацієнток без ознак патології вульви. Число спостережень з високим вмістом естрогенрецепторів у нормальній тканині вульви склало 35,5 \%, тоді як при дистрофії вульви кількість спостережень з високим рівнем рецепторів склала 
Огляди літератури, оригінальні дослідження, погляд на проблему, випадок з практики, короткі повідомлення лише 5,8 \%. При раку вульви в переважній більшості спостережень (85,6 \%) були відсутні естроген-рецептори. У міру збільшення тривалості постменопаузи кількість естроген-негативних результатів при склерозуючому лишаї зростає, складаючи загалом 58,8 \% всіх досліджень (рис. 4).

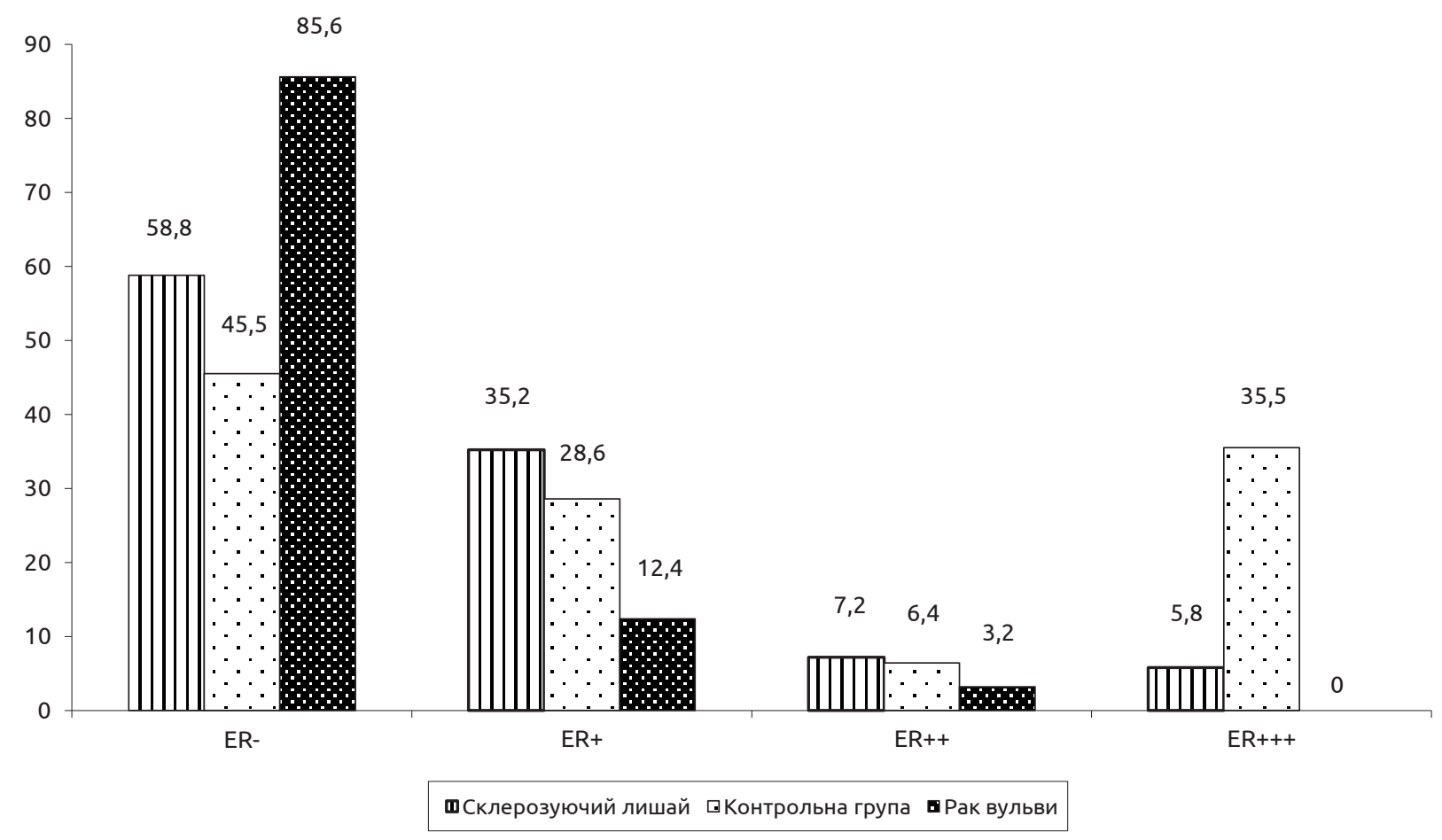

Рис. 4. Рівень естероген-рецепторів у тканині вульви при склерозуючому лишаю та раку вульви.

Результати наших досліджень свідчать про зниження рівня естроген-рецепторів у дистрофічно зміненій тканині вульви до практично повної їх відсутності при злоякісних новоутвореннях.

Уявлення про загальний пул естрогенів у постменопаузі та інтенсивність їх периферійного впливу можна отримати при вимірюванні індексу маси тіла (IMT), що $є$ непрямим свідченням гормонально-рецепторного балансу.

Надлишок маси тіла в постменопаузі як субстрат синтезу естрогенів $\epsilon$ маркером гіперестрогенії. Ми вивчили IMT в обстежуваних групах. Ceред Хворих на РВ виявлено значне перевищення частки жінок зі збільшеним IMT, що склало $86,8 \%$, з них з ожирінням - 45,7\%, а при СЛВ 59,8\% тоді як в групі контролю ІМТ був вище норми лише у $39,0 \%(p<0,05)$ (рис. 5).

На наш погляд, найважливішим ключовим фактором канцерогенезу в тканині вульви $\epsilon$ порушення гормонального метаболізму в постменопаузальному періоді як один із пускових механізмів злоякісної трансформації. Під терміном «гормональний гомеостаз» у постменопаузі ми розуміємо насамперед два важливих компоненти: рівень рецепторного апарата органів-мішеней і рівень експресії естрогенних метаболітів.
Численні дослідження свідчать, що основним фактором, який стимулює клітини естроген-залежних органів до патологічного росту в постменопаузі, $\epsilon$ не сам рівень естрадіолу, а порушення балансу його метаболітів, що мають різну здатність до активації клітинної проліферації. У разі підвищеного вмісту 16а-гідроксиестрону патологічні проліферативні процеси в гормонозалежних органах і тканинах багаторазово посилюються [1, 4-7].

Експериментальними дослідженнями встановлено, що співвідношення метаболітів естрадіолу 2-OHE1/16а-OHE $1 \in$ універсальним біологічним маркером визначення ризику і прогнозу розвитку пухлин в естроген-залежних органах [8-12]. 3 огляду на це ми проаналізували середні рівні метаболітів 2-OHE1 і 16a-OHE 1 при раку i СЛВ у порівнянні з групою контролю.

3 отриманих даних випливає, що при РВ середній рівень фізіологічного метаболіту 2-ОНЕ 1 на $36,8 \%$ нижчий, ніж у групі контролю, а рівень канцерогенного метаболіту 16а-ОЕН 1 на 35,5 \% вищий, ніж у контрольній групі.

При раку вульви коефіцієнт співвідношення метаболітів значно знижувався, складаючи 0,98, що на 53 \% менше, ніж у групі контролю. Результати дослідження вказують на те, що і при СлВ 


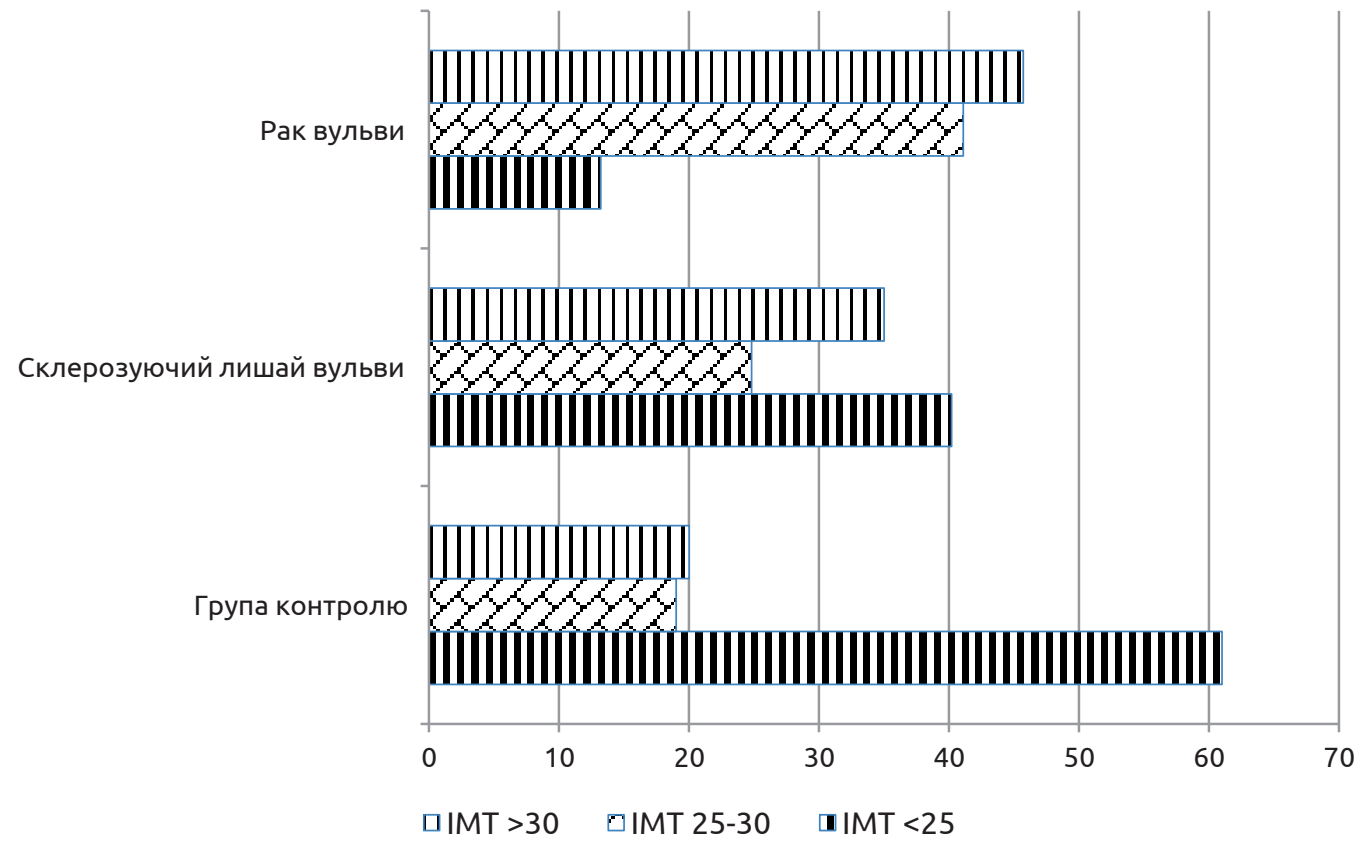

Рис. 5. Індекс маси тіла (IMT) в обстежених хворих.

метаболізм естрогенів більш орієнтований на синтез агресивних метаболітів: коефіцієнт склав 1,76. Таким чином, очевидно, що при РВ має місце підвищеня синтезу агресивних метаболітів, особливо у пацієнток із підвищеним IMT (> $\left.30 \mathrm{kr} / \mathrm{M}^{2}\right)$ i високим проліферативним потенціалом. У жінок із наявністю СлВ також $є$ виражений дисбаланс у співвідношенні похідних естрогенів й унаслідок цього наявні визначені передумови для утворення стійкого проліферативного сигналу в тканині вульви.

Одними з основних ознак початкового етапу формування СЛВ є набряк і лімфогістіоцитарна інфільтрація, що свідчать спершу про запальний (інфекційний) генез. У цьому аспекті, ймовірно, особливе місце належить ролі папіломавірусної інфекції, яка має чітко визначену тропність до плоского епітелію. У всьому світі спостерігається зростання числа хворих, які страждають на папіломавірусну інфекцію геніталій. На сьогодні $є$ дослідження, які вказують на можливу причетність папіломавірусної інфекції до розвитку раку вульви $[1,11,12]$, але навіть у рамках цих доказів не зовсім зрозумілий механізм формування злоякісного процесу, адже вірусоносійство не завжди призводить до розвитку раку. Наявність вірусу хоча й $є$ обов'язковою, необхідний ще ряд умов, при яких запускається і набуває незворотного характеру механізм пухлинної трансформації. Згасання функції яєчників у постменопаузі призводить до зниження синтезу глікогену в епітелії піхви, що зумовлює підвищення лужності піхвового вмісту, створюючи сприятливі умови для розвитку кольпітів. Тому на особливий інтерес заслуговує вивчення інфекційного фактора в патогенезі СЛ і РВ. Особливу увагу в наших дослідженнях було відведено ролі папіломавірусної інфекції, зокрема, диференційному вивченню частоти генотипів високого і низького онкологічного ризику та їх поєднань при СЛВ і РВ, порівняно з групою контролю.

3 огляду на пильну увагу до папіломавірусної інфекції, проведено диференційне вивчення генотипів вірусу папіломи людини (ВПЛ) високого і низького онкологічного ризику та їх поєднань при СЛВ, РВ і в групі контролю. Наші дослідження включали два незалежних варіанти ідентифікації ДНК вірусу папіломи людини (ПЛР і технологія Murex-Digene Hybrid Capture II). При використанні методів ПлР ампліфікацію виділеної ДНК проводили, використовуючи праймери, що дозволяють ідентифікувати 6, 11, 40, 42, 43, 44, 54, 61,70 типи ВПЛ, що належать до низького ступеня ризику, i $16,18,26,31,33,35$, 39, 45, 51, 52, 53, 56, 58, 59, 66, $68,69,73,82$, що належать до генотипів високого ступеня ризику. Настільки великий пошук можливої присутності різноманітних генотипів ВПЛ був продиктований тим, що на перших етапах нашого дослідження, використовуючи методику ПЛР-діагностики за допомогою праймерів для 16 і 18 генотипів, нам вдалося встановити наявність папіломавірусної інфекції в зразках пухлини при РВ в 58,1 \% спостережень. Як свідчать дані дослідження, при СЛВ є вельми широкий і різноманітний спектр типів вірусу папіломи людини. Частота ви- 
Огляди літератури, оригінальні дослідження, погляд на проблему, випадок з практики, короткі повідомлення явлення 16 і 18 генотипів у пацієнток з СлВ складає відповідно 15,5 \% і 25,4 \% спостережень. Набагато частіше діагностували 31 і 52 генотипи 70,6 \% 50,5 \% відповідно. 3 генотипів низького ризику частіше зустрічалися 54,61 і 42 . Найчастіше при РВ виявляли 6 і 11 генотипи - в 45 \% досліджень. Генотипи 16 і 18, що трактуються (на моделі раку шийки матки) як типи високого онкологічного ризику, при РВ виявлено в 30,8 \% і 27,3 \% відповідно (рис. 6).



Рис. 6. Частота виявлення генотипів вірусу папіломи людини (ВПЛ) при склерозуючому лишаю і раку вульви.

У результаті проведених досліджень доведено, що в генезі РВ беруть участь декілька генотипів ВПЛ. Причому найбільше значення при цьому мають ВПЛ 6/11 типів, які, як відомо, належать до ВПЛ низького ризику. Ймовірно, в онкогенній трансформації плоскоклітинного епітелію беруть участь віруси різних типів, тропність яких до певних генотипів тканин органів статевої системи істотно відрізняється. 3 огляду на це ймовірна роль ВПЛ у розвитку РВ може полягати в первісній індукції злоякісного процесу, яка не зберігаються в послідовності у карциномі. Таким чином, проблема вірусного канцерогенезу - це частково, або навіть більшою мірою, проблема взаємодії інфекційної складової з факторами, що визначають різні напрямки постменопаузального гомеостазу.

Проведені дослідження дозволяють переконливо визначитися щодо причетності ряду генотипів ВПЛ до розвитку РВ. Після інфікування ВПЛ у клітинах порушується нормальний процес диференціювання, відбувається клональна екс- пансія ініційованих ВПЛ клітин базального шару, що пройшли тільки первинну стадію диференціювання. Це пов' язано з клітинною трансформацією і подальшою іморталізацією, які здійснюються і контролюються генами ВПЛ, що кодують ранні білки E 6 і E 7. Для доказу етіологічної ролі ВПЛ у розвитку пухлини нами також була вивчена експресія онкобілка E 7 при різних захворюваннях вульви. Незаперечною перевагою $\mathrm{E} 7$ як маркера $\epsilon$ те, що в нормі цей білок в тканинах не синтезується. Його походження повністю пов' язано 3 життєвим циклом інтегративної форми ВПЛ-інфекції. Перевагою також $\epsilon$ те, що для визначення онкобілка E 7 матеріал береться безпосередньо 3 органа-мішені.

У нашій роботі імуноферментний аналіз виконаний в 60 зразках РВ (48 хворих з наявністю ВПЛ у пухлині і 12 хворих без ПЛР-даних про наявність ВПЛ) і в 52 зразках при СЛВ (40 пацієнток без наявності ВПЛ і 12 пацієнток з ПЛР-даними про його наявність) (рис. 7). 
Огляди літератури, оригінальні дослідження, погляд на проблему, випадок з практики, короткі повідомлення
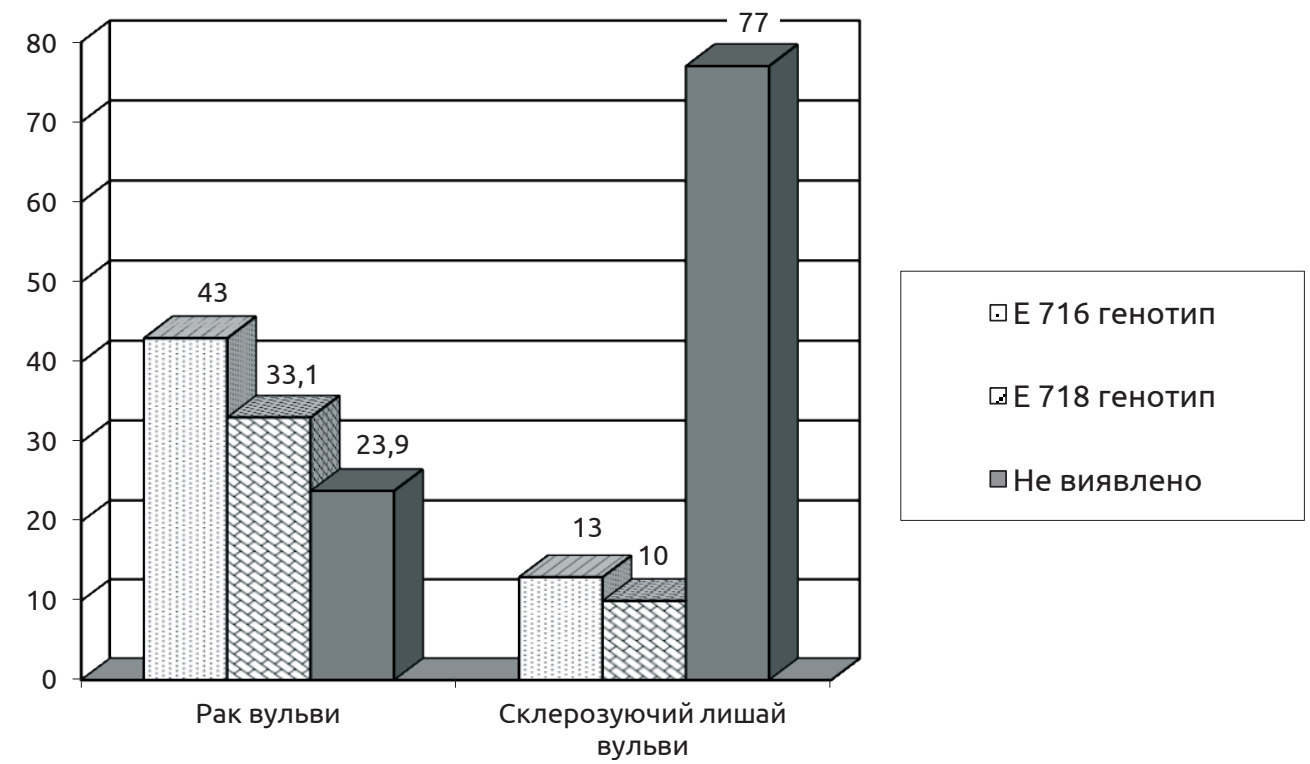

Рис. 7. Онкобілок Е 7 при склерозуючому лишаю і раку вульви.

Позитивні результати отримані тільки в тих пробах, де були генотипи 16 і 18 в 56,7 \% зразків. При вірус-незалежних пухлинних процесах онкобілок $\mathrm{E} 7$ не виявлявся.

При СЛВ онкобілок Е 7 було виявлено тільки у пацієнток з ідентифікованими при ПЛР-діагностиці 16 і 18 генотипами ВПЛ-в $23 \%$.

Однак у 12 спостереженнях з наявністю ВПЛ 16 генотипу і в 10 спостереженнях при ВПЛ 18 генотипу онкобілок не виявлено. Цей факт пояснюється, очевидно, тим, що ВПЛ у цієї категорії пацієнток знаходиться ще в епісомальній формі й не інтегрований у ДНК.

Вивчення синтезу онкобілка Е 7 у вірус-індукованих пухлинах і при передракових захворюваннях має велике значення з діагностичного, лікувального та прогностичного поглядів. Специфічність тесту на білок E7 дозволяє використовувати його в ранній діагностиці РВ, особливо при появі його на фоні наявних дистрофічних хвороб і при виявленні високоонкогенних штамів ВПЛ.

Висновки. Виявляється наступна етапність розвитку процесів, кінцевою ланкою яких $\epsilon$ плоскоклітинний рак вульви. В основі виникнення СлВ лежить естрогенна недостатність. Відсутність естрадіолу призводить до зникнення глікогеновмісних поверхневих клітин, що призводить до підвищення лужності середовища і різкої зміни мікробіоценозу. Формується агресивна мікрофлора з умовно-патогенних, анаеробних бактерій і вірусів. Поряд із змінами поверхневого епіте- лію редукується багата судинна система, багатошаровий епітелій вульви різко стоншується і заміщується сполучною тканиною. Різко зростає частота мікротравм, які доходять до базального шару, що створює умови для тривалого запального процесу. В базальному шарі знаходяться також чутливі до ВПЛ клітини. Після інфікування ВПЛ порушується нормальний процес диференціювання клітин (рис. 8).

Створюються сприятливі умови для переходу вірусної інфекції в інтегративну форму, що супроводжується гіперекспресією онкобілка E 7, особливо в присутності таких факторів як наявність естроген-рецепторів і синтез агресивних метаболітів.

Представлена модель взаємодій ВПЛ і епітелію вульви на фоні її атрофії виникає у обмеженого числа пацієнток постменопаузального періоду, обумовлюючи рівень захворюваності на рак вульви. Найсприятливіші умови, при яких ВПЛ здатний проникнути і взаємодіяти з базальними клітинами, виникають при склерозуючому лишаю: виражене порушення мікробіоценозу вульви і піхви; висока частота інфікування ВПЛ $(99,1 \%$ за даними наших досліджень); свербіж, що призводить до розчухувань, травм і тріщин, i, в результаті, до поширення вірусної інфекції до базального шару. Уявлення про особливості і етіологію виникнення дистрофічних процесів і раку вульви в постменопаузі дозволить сформувати диференційований підхід і до реалізації профілактичних заходів, і в цьому сенсі профілактика набуває патогенетичної спрямованості. 
Огляди літератури, оригінальні дослідження, погляд на проблему, випадок з практики, короткі повідомлення

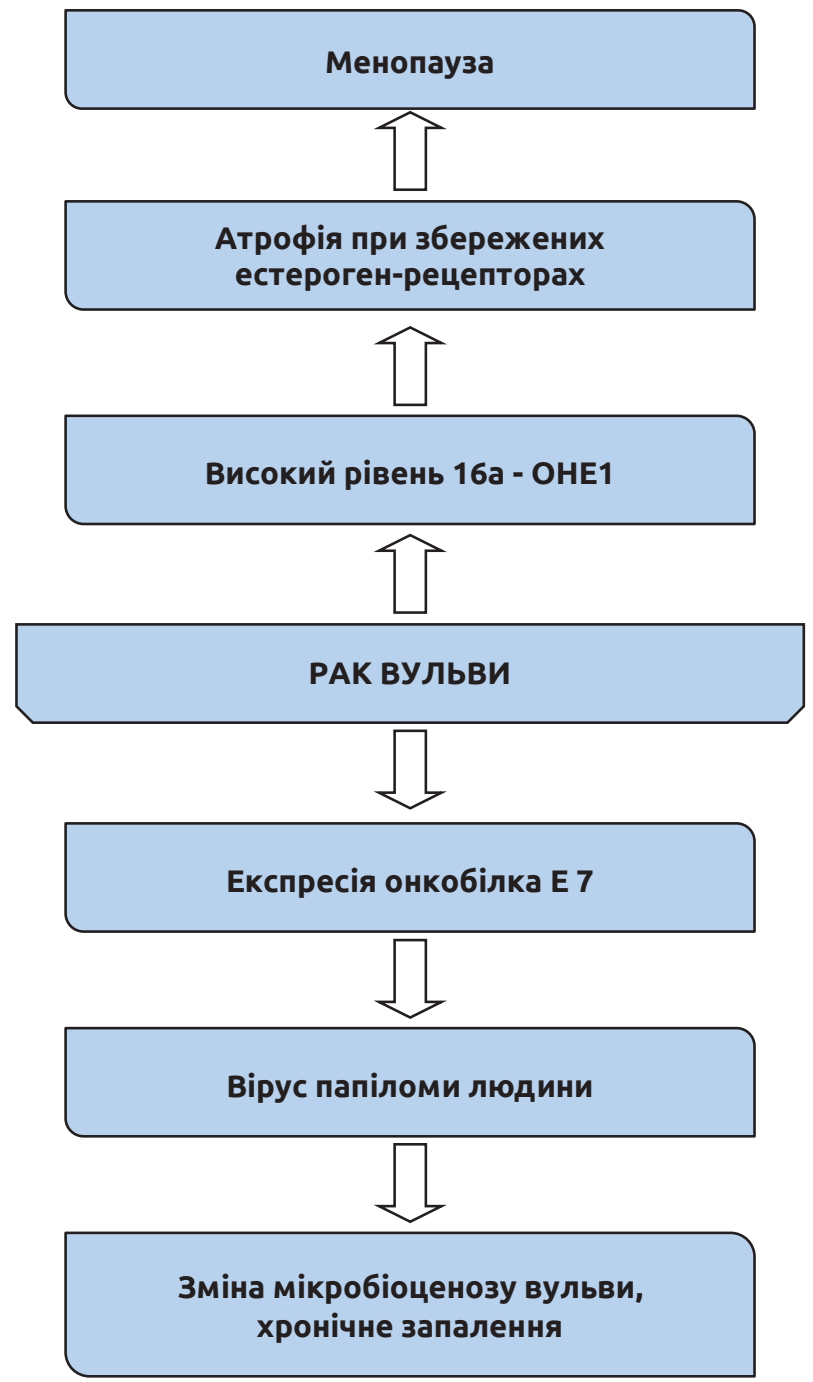

Рис. 8. Фактори впливу на розвиток предраку і раку вульви в постменопаузальному періоді.

\section{ЛІТЕРАТУРА}

1. Урманчеева А. Ф. Эпидемиология рака вульвы. Факторы риска и прогноза / А. Ф. Урманчеева // Практическая онкология. - 2006. - Т. 7, № 4. - С. 189-196.

2. Григорян О. Р. Современные принципы коррекции метаболического синдрома у женщин в период постменопаузы / А. Г. Григорян // Consilium Medicum. 2005. - Т. 7, № 9. - С. 45-47.

3. Черенков В. Г. Рак вульвы: патогенетические варианты, диагностика, лечение, пластическая хирургия / опухоли женского размножения / В. Г. Черенков, И. В. Александрова, А. А. Шпенкова // Системы. - 2010. - № 4. C. $78-83$.

4. Berstein L. M. Hormones of adipose tissue (adipocytokines): ontogenetic and oncologic aspects / L. M. Berstein // Adv. Gerontol. - 2005. - Vol. 16. - P. 51-64.

5. Бутрова С. А. Метаболический синдром: патогенез, клиника, диагноз, подходы к лечению / С. А. Бутрова // РМЖ. - 2001. - Т. 9, № 2. - С. 56.
6. Чернуха Г. Е. Ожирение как фактор риска нарушения репродуктивной системы у женщин / Г. Е. Чернуха // Consilium Medicum. - 2007. - T. 9, № 6. C. $115-118$.

7. Метаболический синдром, взаимосвязь с процессами канцерогенеза эндометрия / А. Л. Чернышева, Л. А. Коломиец, Н. В. Бочкарева, О. Н. Асадчикова // Сибирский онкологический журнал. - 2008. - Т. 29, № 5 (29). - С. 68-74.

8. Ашрафян Л. А. Опухоли репродуктивных органов (этиология и патогенез) / Л. А. Ашрафян, В. И. Киселев. - М. : Димитрейд График Групп, 2007. - 216 с.

9. Киселев В. И. Этиологическая роль папилломы человека в развитии рака шейки матки генетические и патогенетические механизмы, терапия и профилактика // В. И. Киселев, Л. А. Ашрафян, С. А. Бударина // Акушерство и гинекология. - 2004. - Т. 6, № 4. C. 174-179. 
Огляди літератури, оригінальні дослідження, погляд на проблему, випадок з практики, короткі повідомлення

10. Jordan V. C. Selective estrogen receptor modulation: concept and consequences in cancer / V. C. Jordan // Cancer Cell. - 2004. - Vol. 5 (3). - P. 207-213.

11. Hart W. R. Relation of lihen sclerosus et atrophicus of the vulva to development of carcinoma / W. R. Hart, H. F. Norris / Obstet. Gynecol. - 1975. - Vol. 45 (4). P. 369- 377 .

12. Modern approach to classifi cation of precancerous conditions and vulvar dystrophy / S. Djurdjević, D. Segedi, T. Vejnović, J. Vejnović / Med. Pregl. - 1995. Vol. 48 (11-12). - P. 399-404.

13. VIN usual type-from the past to the future / M. Preti, S. Igidbashian, S. Costa [et al.] // Ecancermedicalscience. - 2015. - Vol. 9. - P. 531.

14. Worldwide human papillomavirus genotype attribution in over 2000 cases of intraepithelial and invasive lesions of the vulva / S. de Sanjosé, L. Alemany, J. Ordi [et al.] // Eur. J. Cancer. - 2013. - Vol. 49 (16). - P. 528-535.

15. Nazac A. Neoplasias intraepiteliales de la vulva / A. Nazac, C. Louis-Sylvestre // EMC. Ginecología-Obstetricia. - 2016. - Vol. 52 (3). - P. 1-5.

16. For the Nomenclature committee of the International federation for cervical pathology and colposcopy / J. Bornstein, M. Sideri, S. Tatti [et al.] // J. Low. Gen. Tract. Dis. - 2012. - Vol. 16 (3). - P. 290-295.

17. Evolution of terminology for human-papillomavirus-infection-related vulvar squamous intraepithelial lesions / E. J. Wilkinson, J. T. Cox, M. A. Selim, D. M. O' Connor // J. Low. Gen. Tract. Dis. - 2015. - Vol. 19 (1). - P. 81-87.

18. Imiquimod $5 \%$ cream versus cold knife excision for treatment of VIN 2/3: a five-year follow-up / A. Frega, F. Sesti, F. Sopracordevole [et al.] // Eur. Rev. Med. Pharmacol. Sci. - 2013. - Vol. 17 (7). - P. 936-940.

\section{REFERENCES}

1. Urmancheeva, A.F. (2006). Epidemiologiya raka vulvy. Faktory riska i prognoza [Epidemiology of vulvar cancer. Risk factors and prognosis]. Prakticheskaya onkologiya - Practical Oncology, 7 (4), 189-196 [in Russian].

2. Grigoryan, O.R. (2005). Sovremennyye printsipy korrektsii metabolicheskogo sindroma u zhenshchin v period postmenopauzy [Modern principles of correction of metabolic syndrome in postmenopausal women]. Consilium Medicum, 7 (9), 45-47 [in Russian].

3. Cherenkov, V.G., Alexandrova, I.V., \& Shpenkova, A.A. (2010). Rak vulvy: patogeneticheskiye varianty, diagnostika, lecheniye, plasticheskaya khirurgiya/opukholi zhenskogo razmnozheniya [Vulvar cancer: pathogenetic variants, diagnosis, treatment, plastic surgery/tumors of female reproduction]. Systems, 4, 78-83 [in Russian].

4. Berstein, L.M. (2005). Hormones of adipose tissue (adipocytokines): ontogenetic and oncologic aspects. Adv. Gerontol., 16, 51-64.

5 Butrova, S.A. (2001). Metabolicheskiy sindrom: patogenez, klinika, diagnoz, podkhody k lecheniyu [Metabolic syndrome: pathogenesis, clinic, diagnosis, approaches to treatment]. $R M Z h, 9$ (2), 56 [in Russian].

6. Chernukha, G.E. (2007). Ozhireniye kak faktor riska narusheniya reproduktivnoy sistemy u zhenshchin [Obe-
19. La inmunosupresión es un factor mayor de riesgo de la recidiva de las lesiones del tracto genital inferior asociadas al virus del papiloma humano / P. J. Coronado, M. Fasero, M. Ramírez [et al.] // Prog. Obstet. Ginecol. 2010. - Vol. 53 (5). - P. 179-188.

20. Targeting human papillomavirus to reduce the burden of cervical, vulvar and vaginal cancer and pre-invasive neoplasia: establishing the baseline for surveillance / M. Nygård, B. T. Hansen, J. Dillner [et al.] // PloS One. 2014. - Vol. 9 (2). - P. e88323.

21. Sexual activity and function after surgical treatment in patients with (pre)invasive vulvar lesions / D. Grimm, C. Eulenburg, O. Brummer [et al.] // Support. Care Cancer. 2016. - Vol. 24 (1). - P. 419-428.

22. The Lower Anogenital Squamous Terminology Standardization project for HPV-associated lesions: background and consensus recommendations from the College of American Pathologists and the American Society for Colposcopy and Cervical Pathology / T. M. Darragh, T. J. Colgan, J. Thomas Cox [et al.] // Arch. Pathol. Lab. Med. - 2012. - Vol. 136 (10). - P. 1266-1297.

23. Patología del tracto genital inferior asociada al virus del papilloma humano en mujeres españolas / J. Cortés, X. Castellsagué, A. Torné [et al.] // Prog. Obstet. Ginecol. - 2011. - Vol. 54 (7). - P. 351-357.

24. LAST terminology applied to the vulva: the chatlengue of VIN continues / F. Bogliatto, T. Bohl, J. Reutter [et al.] // J. Low. Gen. Tract. Dis. - 2015. - Vol. 19 (2). P. e47-48.

25. Tumours of the vulva; epithelial tumors. WHO classifcation of tumours of female reproductive organs / C. P. Crum, C. S. Herrington, W. G. McCluggage [et al.]; R. J. Kurman et al. ed. - 4th edn. - IARC Press, 2014.

sity as a risk factor for reproductive disorders in women]. Consilium Medicum, 9 (6), 115-118 [in Russian].

7. Chernysheva, A.L., Kolomiyets, L.A., Bochkareva, N.V., \& Asadchikova, O.N. (2008). Metabolicheskiy sindrom, vzaimosvyaz s protsessami kantserogeneza endometriya [Metabolic syndrome, the relationship with the processes of carcinogenesis of the endometrium]. Sibirskiy onkologicheskiy zhurnal - Siberian Journal of Oncology, 29, 5 (29), 68-74 [in Russian].

8. Ashrafyan, L.A., \& Kiselevyu, V.I. (2007). Opukholi reproduktivnykh organov (etiologiya i patogenez) [Tumors of the reproductive organs (etiology and pathogenesis)]. Moscow: Dimitreyd Grafik Grupp [in Russian].

9. Kiselev, V.I., Ashrafyan, L.A., \& Budarina, S.A. (2004). Etiologicheskaya rol' papillomy cheloveka $v$ razvitii raka sheyki matki geneticheskiye i patogeneticheskiye mekhanizmy, terapiya i profilaktika [Etiological role of human papilloma in the development of cervical cancer, genetic and pathogenetic mechanisms, therapy and prevention]. Akusherstvo i ginekologiya. - Obstetrics and Gynecology, 6 (4), 174-179 [in Russian].

10. Jordan, V.C. (2004). Selective estrogen receptor modulation: concept and consequences in cancer. Cancer. Cell, 5, 207-213. 
Огляди літератури, оригінальні дослідження, погляд на проблему, випадок з практики, короткі повідомлення

11. Hart, W.R., \& Norris, H.F. (1975). Relation of lihen sclerosus et atrophicus of the vulva to development of carcinoma. Obstet. Gynecol., 45, 369.

12. Djurdjević, S., Segedi, D., Vejnović, T., Vejnović, J. (1995). Modern approach to classifi cation of precancerous conditions and vulvar dystrophy. Med. Pregl., 48 (11-12), 399-404.

13. Preti, M., Igidbashian, S., Costa, S., Cristoforoni, P. Mariani, L., Origoni, M., ..., \& Micheletti, L. (2015). VIN usual type-from the past to the future. Ecancermedicalscience, 9, 531.

14. de Sanjosé, S., Alemany, L., Ordi, J., Tous, S., Alejo M., Bigby, S.M., Joura, E.A., Maldonado, P., ..., \& Bosch, F.X. (2013). Worldwide human papillomavirus genotype attribution in over 2000 cases of intraepithelial and invasive lesions of the vulva. Eur. J. Cancer., 49 (16), 528-535.

15. Nazac, A., Louis-Sylvestre, C. (2016). Neoplasias intraepiteliales de la vulva. EMC. Ginecología-Obstetricia, $52(3), 1-5$.

16. Bornstein, J., Sideri, M., Tatti, S., Walker, P., Prendiville, W., \& Haefner, H. (2012). For the Nomenclature committee of the International federation for cervical pathology and colposcopy. J. Low. Gen. Tract. Dis., 16 (3), 290-295.

17. Wilkinson, E.J., Cox, J.T., Selim, M.A., \& O'Connor, D.M. (2015). Evolution of terminology for human-papillomavirus-infection-related vulvar squamous intraepithelial lesions. J. Low. Gen. Tract. Dis., 19 (1), 81-87.

18. Frega, A., Sesti, F., Sopracordevole, F., Biamonti, A., Scirpa, P., Milazzo, G.N., ..., \& Moscarini, M. (2013). Imiquimod $5 \%$ cream versus cold knife excision for treatment of VIN 2/3: a five-year follow-up. Eur. Rev. Med. Pharmacol. Sci., 17 (7), 936-940.

19. Coronado, P.J., Fasero, M., Ramírez, M., Arab, C., Bellón, M., GarcíaSantos, J., \& Vidart, J.A. (2010). La inmu- nosupresión es un factor mayor de riesgo de la recidiva de las lesiones del tracto genital inferior asociadas al virus del papiloma humano. Prog, Obstet, Ginecol., 53 (5), 179-188.

20. Nygård, M., Hansen, B.T., Dillner, J., Munk, C., Oddsson, K., Tryggvadottir, L., ..., \& Krüger Kjær, S. (2014). Тагgeting human papillomavirus to reduce the burden of cervical, vulvar and vaginal cancer and pre-invasive neoplasia: establishing the baseline for surveillance. PloS One, 9 (2), e88323.

21. Grimm, D., Eulenburg, C., Brummer, O., Schliedermann, A.-K., Trillsch, F., Prieske, K., ..., \& Mahner, S. (2016). Sexual activity and function after surgical treatment in patients with (pre)invasive vulvar lesions. Support Care Cancer, 24 (1), 419-428.

22. Darragh, T.M., Colgan, T.J., Thomas Cox, J., Heller, D.S., Henry, M.R., Luff, R.D., ..., \& Wilbur, D.C. (2012). The Lower Anogenital Squamous Terminology Standardization project for HPV-associated lesions: background and consensus recommendations from the College of American Pathologists and the American Society for Colposcopy and Cervical Pathology. Arch. Pathol. Lab. Med., 136 (10), 1266-1297.

23. Cortés, J., Castellsagué, X., Torné, A., Gil, Á., \& SanMartín, M. (2011). Patología del tracto genital inferior asociada al virus del papilloma humano en mujeres españolas. Prog. Obstet. Ginecol., 54 (7), 351-357.

24. Bogliatto, F., Bohl, T., Reutter, J., Sideri, M., \& Bornstein, J. (2015). LAST terminology applied to the vulva: the challengue of VIN continues. J. Low. Gen. Tract. Dis., 19 (2), e47-48.

25. Crum, C.P., Herrington, C.S., McCluggage, W.G., Regauer, S., \& Wilkinson, EJ. (2014). Tumours of the vulva; epithelial tumors. WHO Classifcation of Tumours of Female Reproductive Organs. 4th Edn. Kurman, R.J. (Ed.). IARC Press.

\title{
СОВРЕМЕНННЫЙ ВЗГЛЯД НА ЭТИОЛОГИЮ И ПАТОГЕНЕЗ ПРЕДРАКОВЫХ ЗАБОЛЕВАНИЙ И РАКА ВУЛЬВЫ
}

\author{
○В. В. Дунаевская ${ }^{1,2}$, Т. Ф. Татарчук'1, Н. Ф. Захаренко 3

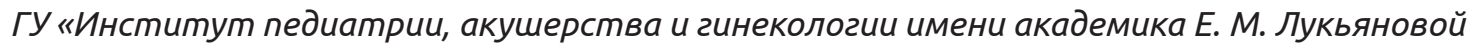 \\ НАМН Украины", Киев' \\ Национальний институт рака, Киев² \\ ГНУ «Центр инновационных медицинских технологий НАН Украины», Киев
}

РЕЗЮМЕ. Проблема дистрофических заболеваний и рака вульВы до настоящего времени остается нерешенной. В последние десятилетия отмечается увеличение числа дистрофических заболеваний вульвы, на фоне которых в $9-49$ \% случаев возникают злокачественные опухоли. Поэтому нужно подробнее рассмотреть эту проблему.

Цель - определить причины развития склерозирующего лишая и рака вульвы.

Материал и методы. Проведено обследование 110 пациенток со склерозирующим лишаем вульвы, 60 больных раком вульвы; 100 пациенток в постменопаузе, не имеющих клинических проявлений заболеваний со стороны вульвы, составили группу контроля.

Результаты. Установлено, что число наблюдений с высоким содержанием эстроген-рецепторов в нормальной ткани вульвы составило 35,5 \%, тогда как при дистрофии вульвы количество наблюдений с высоким уровнем рецепторов составило только 5,8 \%. При раке вульвы в подавляющем большинстве наблюдений (85,6 \%) эстроген-рецепторы отсутствовали. По мере увеличения длительности постменопаузы количество естроген-отрицательных результатов при склерозирующем лишае растет, составляя в целом 58,8 \% всех исследований. 
Огляди літератури, оригінальні дослідження, погляд на проблему, випадок з практики, короткі повідомлення

Выводы. Представление об особенностях и этиологии возникновения дистрофических процессов и рака вульвы в постменопаузе формирует дифференцированный подход к реализации профилактических мероприятий, и в этом смысле профилактика приобретает патогенетическую направленность. Наши исследования показали ключевую роль нарушения соотношения метаболитов эстрогена и вирусной инфекции в патогенезе дистрофических процессов и рака вульвы.

КЛючЕВЫЕ словА: вульва; склерозирующий лишай; менопауза; постменопауза; дисплазия; рак; новообразования; онкобелок; половые губы; папиллома.

\title{
MODERN VIEW ON THE ETIOLOGY AND PATHOGENESIS OF PRE-CANCER DISEASES AND VULVAR CANCER
}

\author{
@V. V. Dunaevskaya ${ }^{1,2}$, T. F. Tatatrchuk ${ }^{1}$, N. F. Zakharenko ${ }^{3}$ \\ O. Lukianova Institute of Pediatrics, Obstetrics and Gynecology of the NAMS of Ukraine ${ }^{1}$ \\ National Cancer Institute, Kyiv² \\ Center for Innovative Medical Technologies of the National Academy of Sciences of Ukraine ${ }^{3}$
}

SUMMARY. The problem of dystrophic diseases and cancer of the vulva still remains unresolved. In recent decades, there has been an increase in the number of degenerative diseases of the vulva, on the background of which from 9 to $49 \%$ of cases malignant tumors appear. Therefore, it is necessary to consider this problem in more detail.

The aim - to determine the causes of sclerosing herpes and vulvar cancer.

Material and Methods. 110 patients with sclerosing herpes of the vulva, 60 patients with vulvar cancer were examined; 100 postmenopausal patients who did not have clinical manifestations of vulvar disease were in the control group.

Results. It was specified that the number of observations with a high content of estrogen receptors in normal vulvar tissue is $35.5 \%$, while in vulvar dystrophy the number of observations with a high level of receptors is only $5.8 \%$. It was noted that in vulvar cancer, estrogen receptors were missing in the vast majority of cases (85.6\%). As the postmenopause duration increases, the number of estrogen-negative results in sclerosing herpes gets higher, accounting for a total of $58.8 \%$ of all studies.

Conclusions. The idea of the features and etiology of dystrophic processes and vulvar cancer in the postmenopausal period forms a differentiated approach to the implementation of preventive measures. In this sense, prevention acquires a pathogenetic focus. Our studies have demonstrated the key role of balance disorder of estrogen metabolite and viral infection in the pathogenesis of dystrophic processes and vulvar cancer.

KEY WORDS: vulva; sclerosing herpes; menopause; postmenopause; dysplasia; cancer; neoplasms; oncoproteins; labia; papilloma.

Отримано 22.09.2020 